Jap. J. M. Sc. \& Biol., 14, 61-68, 1961

\title{
THE EFFECT OF HYDROGEN ION CONCENTRATION AND SALINITY OF WATER ON EXTRUDING RESPONSE AND SURVIVAL OF ONCOMELANIA NOSOPHORA, THE VECTOR SNAIL OF SCHISTOSOMA JAPONICUM IN JAPAN***
}

\author{
KAZUO YASURAOKA \\ Department of Parasitology, National Institute of Health, Tokyo
}

(Received: March 20th, 1961)

Oncomelania quadrasi, the vector snail of Schistosoma japonicum in the Philippines, is said to have been found in waters ranging from $\mathrm{pH} 6.2$ to $\mathrm{pH} 7.8$ and on soils ranging from $\mathrm{pH} 4.6$ to $\mathrm{pH} 7.2$ (Pesigan et al., 1958). On the $\mathrm{pH}$ range conditioning the activity and survival of $O$. nosophora, however, very few reports are available.

As to the effect of sea water on the survival of Oncomelania snails, Muto et al. (1915) and Nagao et al. (1918) noted that when snails were submerged into sea water experimentally all of them died within 49 hours and 4 to 6 days, respectively. Practically, the habitat of $O$. nosophora in Suzunuma district of Shizuoka Prefecture was flooded with sea water in July 1917 and as a result of this almost all snails were found dead (Muto et al., 1918). The present report gives data concerning the effect of $\mathrm{pH}$ and salinity on the extruding responce and survival of $O$. nosophora.

\section{MATERIALS AND METHODS}

Snails: Oncomelania nosophora used in this experiment were collected from the suburbs of Kofu City in Yamanashi Prefecture. Up to the commencement of experiment they were kept off the water for two or three days in the laboratory. Only snails which were actively moving when placed in dechlorinated water were selected for the experiment.

$p H$ : Sixteen series of water with various $\mathrm{pH}$ values, namely $2.2,2.7,2.9,3.3,3.5,4.0$, $4.2,5.6,7.2,7.5,8.9,9.2,10.0,10.4,11.1$ and 11.3 , were produced by the addition of different amounts of $\mathrm{N} / 10 \mathrm{HCl}$ or $\mathrm{N} / 10 \mathrm{NaOH}$ into distilled water. During the experiment the $\mathrm{pH}$ value was measured three times, at the beginning, in the middle and at the termination of the experiment, by means of Hitachi $\mathrm{pH}$ Meter. The $\mathrm{pH}$ value during the period of experiment varied by only \pm 0.1 from the starting $\mathrm{pH}$.

Salinity: To make the experimental condition as simple as possible, Herbst's artificial sea water $\left(5 / 9 \mathrm{M} \mathrm{NaCl} 100,5 / 9 \mathrm{M} \mathrm{KCl} 2.1,10 / 27 \mathrm{M} \mathrm{CaCl} 23.4\right.$ and $\left.10 / 27 \mathrm{M} \mathrm{MgCl}_{2} 15.9\right)$ was used. The $\mathrm{pH}$ value in this mixture varied between 6.2 and 6.4.

Observations: (1) Extruding response: When a snail was put into water, it opens the operculum, initially streches out the foot gradually and the head with the tentacles later. The grade of the response was classified " + " when they opened the opercula and stretched the feet and heads: " \pm " when they only slightly opened the opercula: and "-" when their opercula

\footnotetext{
* This work was supported partly by the grant aid from the National Institutes of Health of the United States.

** Studies on the behavior of Oncomelania nosophora. No. 3

安羅岡 一男 (国立予防衛生研究所奇生虫部)
} 
remained closed. In this paper, however, the response such as " \pm " will be included in "-" to facilitate understanding of the general feature of the phenomena observed. The response was measured by the percentage of snails which responded.

(2) Survival: At the conclusion of exposure all snails were rinsed with distilled water, laid in dechlorinated water for 24 hours and then examined for survival or death. Snails were judged as dead when they showed no movement after their transfer into water. Those which showed no movement were dissected afterwards to confirm their death.

\section{RESULTS}

\section{Extruding Response in Various pH Values.}

Thirty snails were put into a reagent bottle (wide mouth), $10 \mathrm{~cm}$ in diameter and $15 \mathrm{~cm}$ in height, containing $750 \mathrm{cc}$ of water with various $\mathrm{pH}$ values, and their extruding responses were observed. The temperature during the period of observation ranged from $24^{\circ}$ to $26^{\circ} \mathrm{C}$. Fig. 1 shows the results of the observation. As early as one hour after placing snails into water, all snails showed the extruding response in each series between $\mathrm{pH} 4.0$ and 10.0. At $\mathrm{pH} 10.0$, however, the number of snails which responded decreased slightly with the lapse of time and six hours later, only 25 or $83 \%$ of the

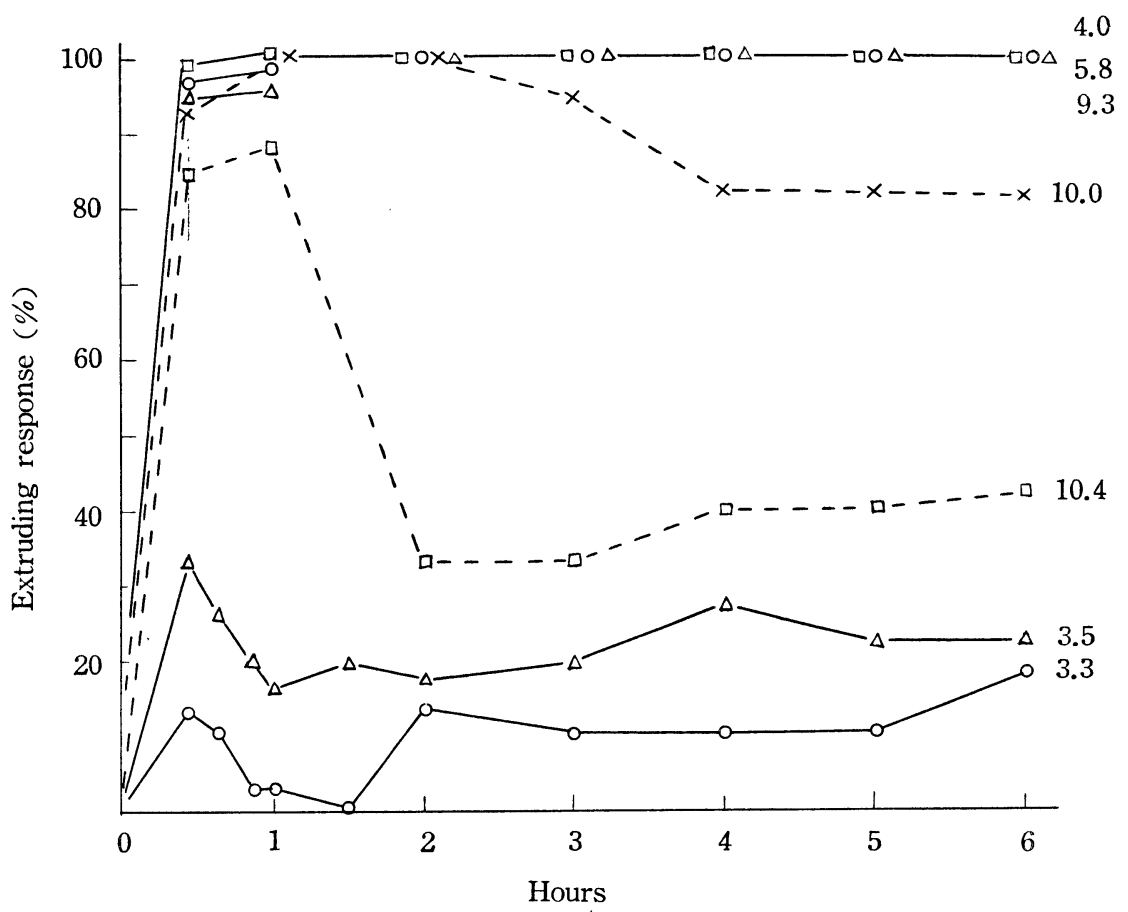

Fig. 1. The extruding response of $O$. nosophora in waters of various $\mathrm{pH}$ values $\left(24^{\circ} \mathrm{C}-26^{\circ} \mathrm{C}\right)$.

snails showed the response. At $\mathrm{pH} 10.4$, one hour later, 26 or $87 \%$ of the snails showed the response, but afterwards began to pull in their head, and two hours later, the percentage of the number of snails which responded varied slightly from $30 \%$ to $40 \%$. At $\mathrm{pH} 3.5$ and 3.3 , the percentage was $17 \%$ and $13 \%$, respectively after two hours. Such a state of the response continued for the following six hours. In acid waters such 
as below $\mathrm{pH} 2.9$ and in alkaline waters such as above $\mathrm{pH} 11.1$ no extruding response was observed at all. Fig. 2 shows the percentage of the number of snails which responded in various $\mathrm{pH}$ values after 6 hours.

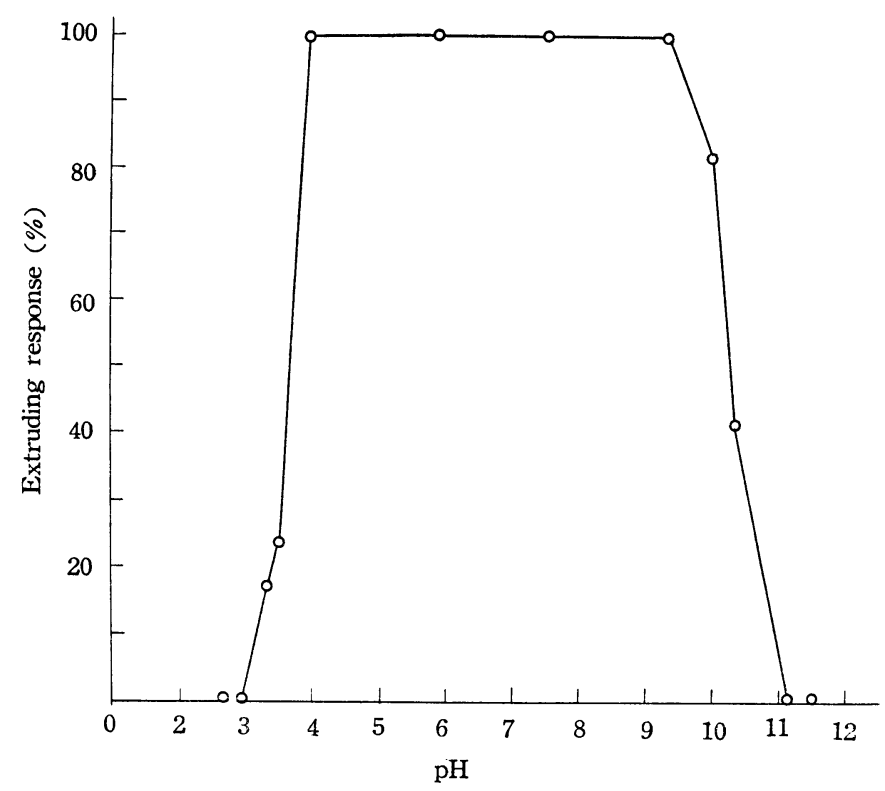

Fig. 2. The summary of extruding response of $O$. nosophora in various $\mathrm{pH}$ values 6 hours after placing in water $\left(24^{\circ} \mathrm{C}-26^{\circ} \mathrm{C}\right)$.

\section{Survival in Various pH Values.}

The apparatus used in this experiment was the same as that used in the previous section except the following point: before placing snails into waters of various $\mathrm{pH}$ values, twenty snails were put into a pouch made of gauze to prevent them from creeping out of water. In each $\mathrm{pH}$ series 3 pouches or 60 snails were used. After 24, 48 and 72 hours' application snails in each $\mathrm{pH}$ series were examined for their death. The temperature during the period of observation ranged from 24.5 to $27.0^{\circ} \mathrm{C}$. The results are shown in Fig. 3. Twenty four hours later, as seen in the figure, the mortality of snails placed into acid waters such as $\mathrm{pH} 2.9,2.7$ and 2.3 and alkaline ones such as $\mathrm{pH} 10.4,11.0$ and 11.3 was less than $30 \%$; and 72 hours later, the mortality rose to $50 \%$ at $\mathrm{pH} 2.9,35 \%$ at $\mathrm{pH} 2.7,95 \%$ at $\mathrm{pH} 2.3,55 \%$ at $\mathrm{pH} 10.4$, $35 \%$ at $\mathrm{pH} 11.0$ and $80 \%$ at $\mathrm{pH} 11.3$. Fig. 4 shows the summary of mortality of snails in waters of various $\mathrm{pH}$ values after 72 hours. No snails were found dead, within 72 hours, in each series between $\mathrm{pH} 3.3$ and 9.2.

\section{Extruding Response in Different Concentrations of Sea Water.}

Twenty snails were put into the same bottle as used in the previous sections containing $750 \mathrm{cc}$ of different concentrations of sea water, and their extruding responses were observed one hour after the exposure. The temperature during the period of experiment was $18 \pm 1^{\circ} \mathrm{C}$. Fig. 5 shows the results of the observation. As seen in this figure, all snails showed the extruding response in concentrations of sea water less than $30 \%$, 


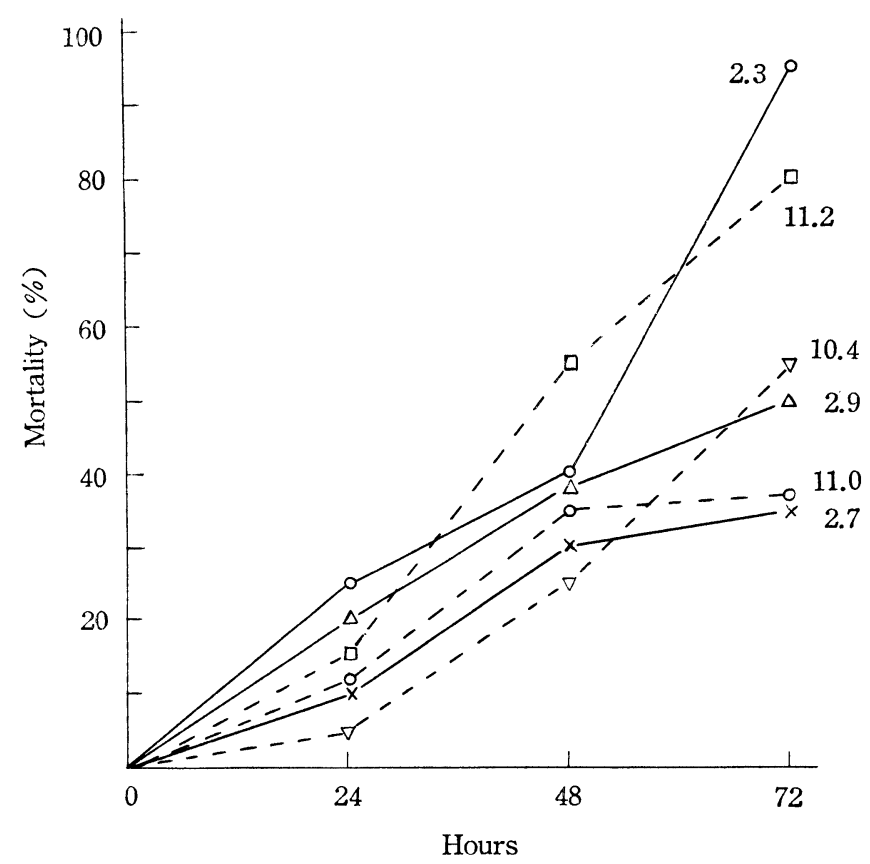

Fig. 3. The mortality of $O$. nosophora in waters of various $\mathrm{pH}$ values $\left(24.5^{\circ} \mathrm{C}-27.0^{\circ} \mathrm{C}\right)$.

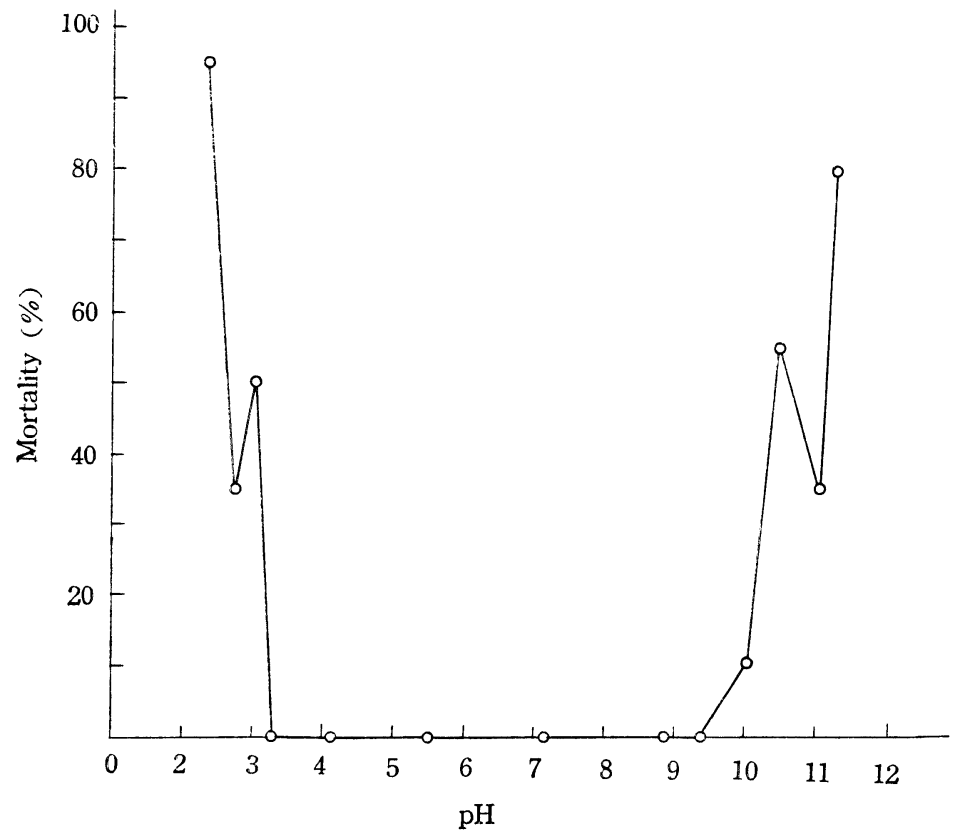

Fig. 4. The summary of mortality of $O$. nosophora in waters of various $\mathrm{pH}$ values 72 hours after placing $\left(24.5-27.0^{\circ} \mathrm{C}\right)$. 
whereas no such response was observed in sea water more than $31.7 \%$. The threshold concentration of sea water to induce the response, therefore, exists between $30 \%$ and $31.3 \%$.

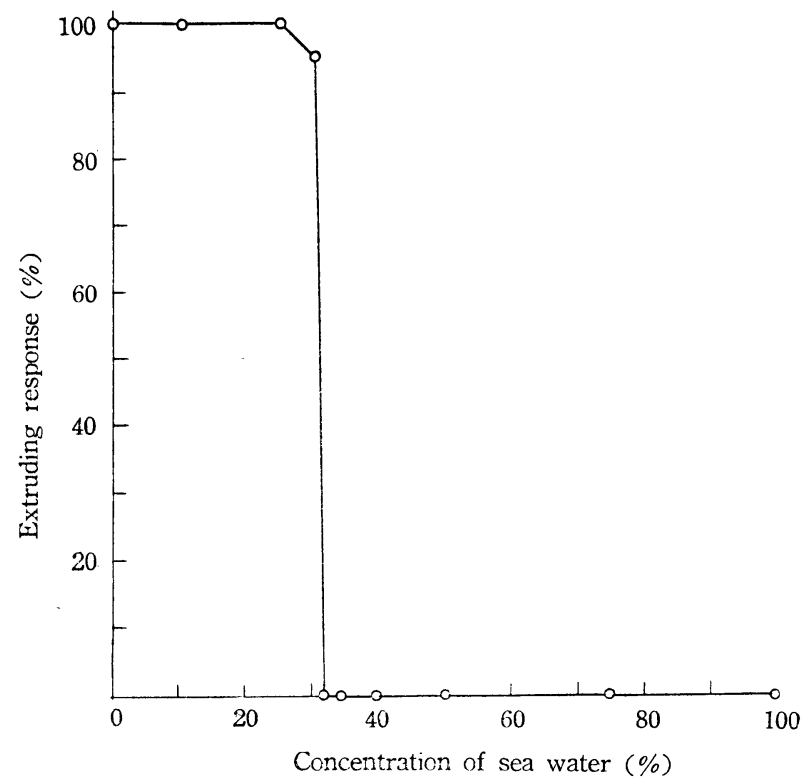

Fig. 5. The summary of extruding pesponse of $O$. nosophora in different concentrations of artificial sea water 1 hour after exposure $\left(18 \pm 1^{\circ} \mathrm{C}\right)$.

\section{Survival in Different Concentrations of Sea Water.}

Twenty snails placed in a gauze pouch were put into a bottle containing $750 \mathrm{cc}$ of sea water of different concentrations. After 2, 4 and 6 days, the snails in each concentration were examined for viabily. The temperature during this experiment was $18-25^{\circ} \mathrm{C}$. The results are shown in Fig. 6. Two days laters, as seen in the figure, the mortality of snails being put into $100 \%$ sea water was less than $15 \%$; and 6 days later, the mortality rose to $90 \%$ in $100 \%$ sea water, $80 \%$ in $75 \%, 50 \%$ in $50 \%$ and $5 \%$ in $25 \%$ sea water. No snails were found dead, within 6 days, in $10 \%$ sea water.

\section{Effect of Salinity on Extruding Response and Survival.}

As already mentioned above, all snails showed the extruding response in concentrations of sea water less than $30 \%$. From the viewpoint of osmotic pressure, therefore, all snails should show the response in aquatic solutions of $\mathrm{M} / 8 \mathrm{NaCl}, \mathrm{M} / 8 \mathrm{KCl}, \mathrm{M} / 12$ $\mathrm{CaCl}_{2}$ and $\mathrm{M} / 12 \mathrm{MgCl}_{2}$. To know whether the effect was caused by a salt or an ion the following experiment was performed in the single salt solution at first and then in the mixture of them.

The apparatus and the methods used in this experiment were essentially the same as those used in the previous section. The mixtures of single salt solutions were prepared in the same portions as they are in artificial sea water. The composition of the various 


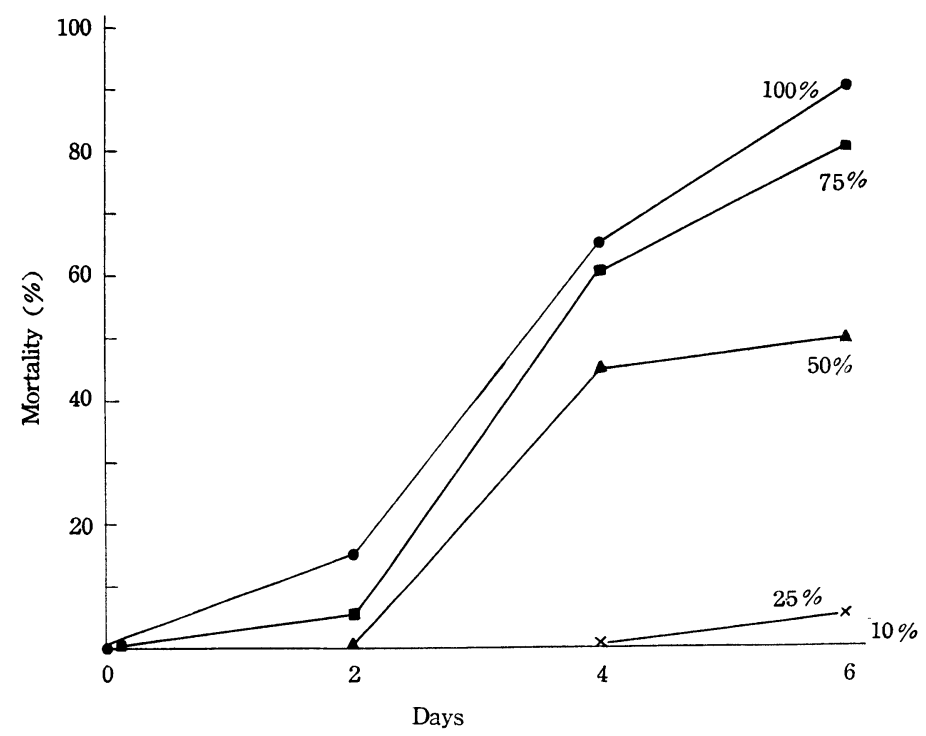

Fig. 6. The mortality of $O$. nosophora in different concentrations of artificial sea water $\left(18-25^{\circ} \mathrm{C}\right)$.

solutions used in this experiment is shown in Fig. 7. The observations were made after one hour for the extruding response and after 72 hours for the survival. The temperature during the period of experiment ranged between $18^{\circ} \mathrm{C}$ and $22^{\circ} \mathrm{C}$. The results are summarized in Fig. 7. The rates of the response in four single salt solutions, as seen in the figure, were $0 \%$ in $\mathrm{M} / 8 \mathrm{NaCl}, 0 \%$ in $\mathrm{M} / 8 \mathrm{KCl}, 5 \%$ in $\mathrm{M} / 12 \mathrm{CaCl}_{2}$ and $15 \%$ in $\mathrm{M} / 12 \mathrm{MgCl}_{2}$. Such an inhibitory effect of $\mathrm{NaCl}$ on the response, however, was decreased by the addition of other salts, especially of $\mathrm{CaCl}_{2}$. The highest rate of the

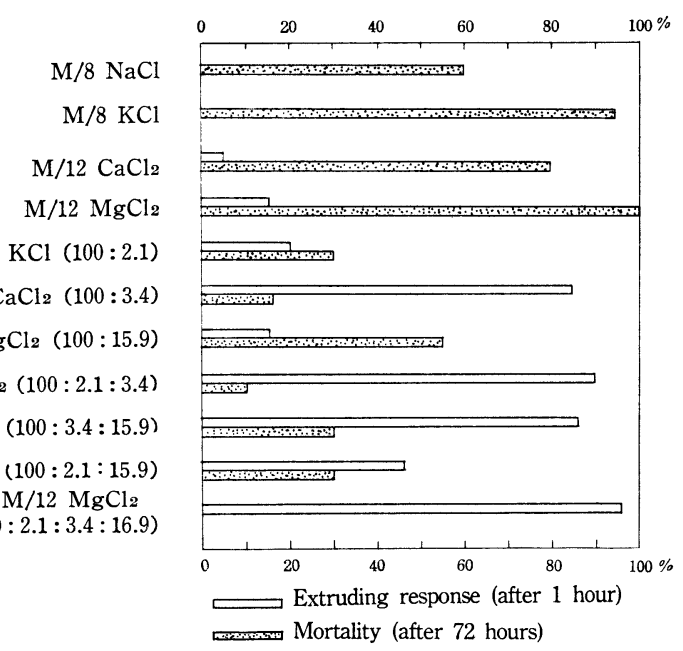

Fig. 7. The extruding response and mortality of $O$. nosophora in various salt solutions $\left(18-22^{\circ} \mathrm{C}\right)$. 
response was found in the mixture solutions of four salts, $\mathrm{NaCl}, \mathrm{KCl} \mathrm{CaCl} 2$ and $\mathrm{MgCl}_{2}$.

On the other hand, the mortalities of snails in the four single salt solutions were found to be higher than those in the mixture of them of the same concentration. The lowest mortality was found in the mixture solution of four salts. Thus, the toxic effect of $\mathrm{NaCl}$ on snails was decreased by the addition of the other salts, especially of $\mathrm{CaCl}_{2}$.

\section{DISCUSSION}

According to WHO Technical Report Series No. 120 (1958), Bulinus truncatus, Biomphalaria adowensis and Australorbis glabratus, schistosoma-bearing snails, can be bred between $\mathrm{pH} 4$ and $\mathrm{pH} 10$. As already seen in Figs. 2 and 4, O. nosophora has also a wide limit of tolerance to $\mathrm{pH}$. Although laboratory data cannot safely be transposed to field situations, the present study suggests that $O$. nosophora has rather a wide range of $\mathrm{pH}$ for its distribution.

Muto et al. (1915) and Nagao et al. (1918) stated that when snails were submerged into sea water experimentally all of them died within 49 hours and 4 to 6 days, respectively. The data in Fig. 6, however, indicate that when snails were submerged into $100 \%$ sea water $10 \%$ of them still survived in it for 6 days. In the experiments of Muto et al. and Nagao et al. natural sea water was used, whereas artificial sea water was used in the present study to make the experimental condition as simple as possible. It is said that in case natural sea water is used for laboratory experiment it should be decayed before use by placing it in the laboratory for a long time because it contains various organic matters. However, no description on this point is available in previous works mentioned. In addition, no information is available about the temperature in their papers. The wide difference among Muto's, Nagao's and the present author's results may be ascribed either to the use of different sea waters or to the application of different temperatures during the period of experiment.

Single salt solutions, $\mathrm{M} / 8 \mathrm{NaCl}, \mathrm{M} / 8 \mathrm{KCl}, \mathrm{M} / 12 \mathrm{CaCl}_{2}$ and $\mathrm{M} / 12 \mathrm{MgCl}_{2}$, as seen in Fig. 3, have high inhibitory and toxic effects on the extruding response and survival of snails. The inhibitory and toxic effects of $\mathrm{NaCl}$, however, were decreased by the addition of the other salts, namely $\mathrm{KCl}, \mathrm{CaCl}_{2}$ and $\mathrm{MgCl}_{2}$. The possibility that $\mathrm{Na}, \mathrm{K}, \mathrm{Ca}$ * and $\mathrm{Mg}{ }^{*}$ ions have antagonistic action to one another on the activity and survival of snails must be admitted. It is suggested that high salinity such as sea water has an important role in regulating the activity of snails and in limiting their distribution.

\section{SUMMARY}

To know the effect of $\mathrm{pH}$ and salinity on the extruding response and survival of $O$. nosophora, several experiments were carried out and the results are summarized as follows :

1. All snails showed the extruding response in waters ranging from $\mathrm{pH} 4.0$ to 9.2 .

2. No snails were found dead, within 72 hours, in waters ranging from as low as $\mathrm{pH} 3.3$ to as high as $\mathrm{pH} 9.2$.

3. The threshold concentration of sea water to induce the extruding response of snails exists between $30 \%$ and $31.3 \%$.

4. The mortalities of snails submerged into $100 \%, 75 \%, 50 \%, 25 \%$ and $10 \%$ sea water for 6 days were $90 \%, 80 \%, 50 \%, 5 \%$ and $0 \%$, respectively. 
5. $\mathrm{Na} \cdot \mathrm{K}^{\bullet}, \mathrm{Ca}{ }^{*}$ and $\mathrm{Mg}^{*}$ ions have an antagonistic action to one another on the extruding response and survival of snails.

6. High salinity such as sea water has an important role in regulating the activity of snails and in limiting their distribution.

Author's acknowledgements and indebtedness are due to Dr. Y. Komiya, Chief of Department of Parasitology, National Institute of Health of Japan, for his kind advice and generous encouragement. Thanks are also due to Dr. T. Iijima of Yamanashi Prefectural Hygine Laboratory for materials used in this work.

\section{REFERENCES}

MUTO, M. \& USAMI, K. (1915): An opinion on the prevention of Schistosomiasis japonica in Shizuoka Prefecture. "Tokyo Iji Shinshi", 1937, 1907-1910 (text in Japanese).

Muto, M. \& UsAmI, K. (1918): On the effect of sea water on Oncomelania nosophora, in a flooded district of Shizuoka Prefecture. "Chuo Igaku Zasshi", 25, 81-89 (text in Japanese).

NAGAO, M. \& KATO, S. (1918): The exterminatory measures of Oncomelania nosophora, an intermediate host of Schistosoma japonicum. "Nihon Shokakigakkai Zasshi", 17, 25-42 (text in Japanese).

Odum, E. P., (1953) : Fundamentals of ecology. W. B. Saunders Company, Philadelphia.

Pesigan, T. P., Hairston, N. G., Jauregui, J. J., Garcia, E. G., Santos, A. T., Santos, B. C. \& BESA, A. A. (1958): Studies on Schistosoma japonicum infection in the Philippines 2. The molluscan host. Bull. World Health Org., 18, 481-578.

W. H. O. (1957) : Technical report series, No. 120. 